\title{
Overheads cost research dear
}

Revelations about research universities that have charged the US government for yachts and other baubles have made new rules on indirect research costs inevitable. None too soon. But will the new rules be fair and flexible?

RESEARCH institutions in the United States receive some $\$ 6,000$ million a year from the National Institutes of Health (NIH) for the direct costs of biomedical research. The same institutions garner another $\$ 2,000$ million in overhead, euphemistically called indirect costs. Thus, NIH pay their share of the costs of running the university library and the president's office when they award a research grant. They pay for heat and light. Recently, the US Congress and public learned to their dismay that occasionally $\mathrm{NIH}$ (which is to say the taxpayer) also pay part of the costs of university yachts, antiques, fancy receptions and university-owned shopping malls. The revelations have been widely called a scandal. They are.

Nobody suggests that research institutions should (or could) meet out of their own resources the costs of providing an environment in which research projects can flourish. And it is unlikely that Stanford University, one of the most distinguished of research universities anywhere, is alone in having abused the system. But the university has given great offence by declaring at a congressional hearing that many of the challenged indirect cost charges were, by arcane accounting agreements, perfectly legal.

Now, government auditors have been despatched to review the books at a couple of dozen leading research universities, while the universities themselves have called in their own auditors. Harvard has announced already that it will withdraw at least $\$ 500,000$ in overhead charges; Massachusetts Institute of Technology (MIT) is withdrawing more than $\$ 730,000$ from its claims for indirect costs. According to MIT records, $\$ 68,000$ charged against overhead was spent on a Washington, DC, law firm that lobbied on the institution's behalf when Congress held a hearing on a paper coauthored by David Baltimore, then at MIT.

\section{Outrage}

Stanford has come in for the brunt of the criticism in this affair. The university's claim that some of its challenged charges were legal is an outrage to common sense. Television shots of its $\$ 72,000$ yacht and the president's elegant mansion have given an impression of academics as high-rollers, not tweedy or white-coated scholars. Stand-up comedians are having a field day at the university's expense.

But the scandal cuts much deeper. It has seriously damaged the image of universities nationwide as honest trustworthy brokers of public money. Furthermore, it reveals a system of government auditing in both the Department of Health and Human Services and the Department of Defense - the two agencies that audit the books of research universities - that certainly needs repair. It is not that universities have conspired en masse to bilk the government. Rather, a system has grown up that allows them to recover some costs that auditors have approved but that, when brought to light, cannot possibly be justified as a cost of doing scientific research.

\section{Tensions}

What universities have lost in public trust is incalculable. What they stand to lose in dollars is not, and seems to be quickly adding up to millions. And this will hurt. It is important to remember that most indirect cost charges cover an unglamorous part of research - things such as heat, light, electricity, security and the library. The rules for allocating them are complex and make for reading that only an accountant could love. It has been hard to get anyone really to pay attention even though the issue has been simmering for some time, largely because indirect costs have been a rising proportion of direct research costs. Faculty at many universities have complained that they are being ripped-off by overstaffed and overpaid administrative offices, thereby creating unhealthy tensions between the faculty and university administrators.

Recognition that the system is in trouble has been widespread. The Association of American Universities produced a major analysis and set of recommendations only a couple of years ago. For the past 18 months, the association has been negotiating with the government's Office of Management and Budget to help reform the system, but the negotiations were suspended when Congress and the Bush Administration got into the act during the past few weeks. These manoeuvres nevertheless point the way to a likely resolution, one that will include a percentage cap across the board and new rules about which charges are allowable and which are not.

This is all to the good and long overdue. The scandal about yachts and antiques and lawyers' bills has had the salutary effect of focusing minds on an issue that deserves the attention it is now getting.

But a potentially more serious issue is the way in which the high costs of new buildings can be redistributed as indirect costs. The obvious danger is that zealous attempts to outlaw conspicuous abuse will generate inflexible rules that damage the research enterprise. 